\title{
THE AMERICAN SECURITIES ACT AND ITS FOREIGN COUNTERPARTS: A COMPARATIVE STUDY
}

\section{FRIEDRICH KESSLER $\dagger$}

T HE likeness of parts of the Securities Act to the corresponding provisions of the British Companies Act of 1928-9 has caused many reviewers of the Securities Act to compare it, either incidentally or fully, with the cognate provisions of the English Act. ${ }^{1}$ A more comprehensive comparative study, including the most important Continental legal systems, has not yet been written. This article attempts that study.

Before going into the details of comparison, it seems necessary to point out the peculiar difficulties which have to be overcome in this field of investigation. First, the mechanisms employed in the different continental legal systems to protect the investor, unlike those of the Securities Act, are not bodies of rational thoughts, but are comparable rather to an old, badly constructed building, which has been more and more enlarged in the course of generations. They differ materially not only in details but also in the main lines, so that it is very difficult to give a survey which evades the scylla of being too abstract and general, as well as the charybdis of incorporating too many perplexing details. Second, the fact that it is necessary in the interest of avoiding the overloading of the article to limit the analysis to only the most important and interesting continental securities legislation raises the difficulty that the selection of the legislation cannot be free from some arbitrariness. Third, a fruitful comparison demands that the study should not remain purely on the legalistic level, but should give a report of the practical experiences under the different legal systems. But as soon as we leave the legalistic level, the difficulties are increased. Most of the statements relating to the efficiency of legal provisions are to be met with the utmost caution, because very often their authors are not at all impartial. Either they are

†Privatdozent at the Handelshochschule, Berlin; Rockefeller Fellow doing resarch vork: at Yale School of Law; author of treatises and articles in German legal periodicals, dealing with comparative law and other subjects.

1. Bates, (November 1933) Bulletin of the Harvard Business School Alumni Acsocintion 31; Barnett, The Securities Act of 1933 and the British Companies Act (1935) 13 Errv. Bus. Rev. 1; Frankfurter, The Federal Sectrities Act: II (1933) 8 Fonturi 53; Hann3 and Turlington, The Securities Act of 1933 (1933) 7 So. Carrr. L. Rev. 18. 
consciously or subconsciously, on account of their social standing, representatives of economic groups interested in the preservation of the status quo, ${ }^{2}$ or their attacks on the prevailing system made for the most part in general terms, are more the expression of a sympathetic enthusiasm than of a complete insight into the complex situation. We find for example, that distinguished French authors admire certain rules of the German law, advocating their introduction into the French system while the same rules are not at all approved by competent German writers. ${ }^{8}$

The best method of getting a proper basis for our investigation seems to be to begin with the aims of the Securities Act and the means which the American legislator has deemed suitable to accomplish his aims. As has been pointed out repeatedly, the Securities Act tries to put at the disposal of an investor all the information which is deemed necessary to enable him to form an intelligent judgment regarding the merits of a security. One may add to this function the further one of protecting the investor against misstatements or omissions in the sale of securities. For our present purpose it is sufficient to state that the Act tries to accomplish its purpose by prescribing that no offer for the interstate sale of any security covered by the Act can be made either by the issuer or by an underwriter or dealer, unless a registration statement, giving a large amount of information about the security to be issued, is filed with the Securities and Exchange Commission, and has become effective, and a prospectus summarizing the information in the registration statement has been handed over to the buyer. The requirements relating to complete registration statements and prospectuses are fortified by civil and penal provisions relating to misstatements and omissions. In addition to the rules requiring registration, the Act contains general provisions penalizing any untrue statement in sales of any security, whether the registration and prospectus requirements were applicable to their issuance or not, supplementing in this respect many state blue-sky laws and the common law. The Act regulates only the issuance of new securities, the protection of the investor in connection with subsequent trading in them being provided by the Securities Exchange Act. Though the provisions of the latter are not included in this article, the provisions of the Continental laws which correspond to it could not be entirely left out of the picture. They are dealt with only in a very summary way, insofar as it is necessary to complete the picture. Very often the provisions of the Continental legal systems which are to be dealt with can only be fairly appreciated if one takes into account the manner of, and the extent to which they are supplemented by rules and regulations contained in the different stock exchange laws.

2. von Nell-Bruentivg, Aktiengesectschaft und Moral (13 Gesellschaftsrechtlicho Abhandlungen, herausgegeben von Arthur Nussbaum, 1930) 8 et seq.

3. See infra page 1151 . 
The provisions of the Securities Act not only try to protect those persons who want to invest their money in shares and bonds issued by corporations, but extend their protection to all sorts of other securities purchases, issued by natural persons, partnerships, committees and trusts. Here we are facing the first important discrepancy between the American Act and most of the Continental legal systems. The Securities Act is much more comprehensive, not only than the English Companies Act, ${ }^{4}$ but also than all Continental statutes including even the French statute of January 30,1907 , which adopted a very extended protective system. ${ }^{5}$ The majority of the Continental statutes have built up provisions for the protection of the investor in stocks; a relatively smaller group of statutes extends the provisions to purchases of bonds; ${ }^{\circ}$ and only a very small group, following the French example, go still further, the protective provisions being applicable whenever securities negotiable on the stock exchange or through banks are offered to the public by any business association, be it a corporation, a partnership, or the like. The following investigation will deal only with the provisions relating to purchases of stock, the provisions relating to bonds, so far as they exist, being in the main the same.

A comparative study of those parts of the Securities Act which have been created for the protection of an investor who buys shares of a corporation should not lose sight of the fact that the Securities Act is not a general incorporation statute. It leaves the various corporation laws untouched on principle, but brings uniformity into that part of the corporation system in which uniformity is of the greatest value to the investor. Since State legislation on securities had failed to check the distribution of unsound securities, partly on account of the variance in the requirements of the several state statutes, ${ }^{8}$ it was found necessary that the federal act unify the laws relating to securities issued, insofar as these matters are subject to the legislative power of Congress under the interstate commerce clause. On the other hand, the continental statutes are, with the exception of the French and Belgian laws, not Securities acts, but corporation statutes. This structural difference of the respective acts accounts for many of the principal discrepancies in the different protective systems. We will deal with them before going into the details of comparison.

\footnotetext{
4. Barnett, supra note 1 , at 2.

5. See infra pages $1140,1144$.

6. Belgium: Law of July 22, 1913, MorrTeUR July 25, 1913, art. 82. France: Lav of January 30, 1907, 405 Bulletin des Lois 1433, art. 3.

7. France: Law of January 30, 1907, 405 Bulletin des Lois 1433, art. 3 and the comment in 2 Houpin et Bosviedx, Tratré Générar des Soctétés (6th ed. 1929) n. 1804 et seq.

8. Hearings before Committee on Interstate and Foreign Commerce on the Securilies
} 
The fact that the protective provisions in most of the continental legal systems form a part of their corporation law influences the mechanism of protection. They are more closely connected and attuned to the individual corporation laws than is the Securities Act. The protective provisions of the continental legal systems reflect, therefore, the peculiarities of the Continental corporation laws and the differences of the latter from the Anglo-American systems. In this connection, it is necessary to understand a fundamental distinction between the American and the Continental methods of capitalization of business corporations. According to the American corporation laws, a corporation must usually first be organized before stock may be offered for subscription in exchange for property or cash. If the corporation needs capital after this first issuance of stock, the capital can be raised either by selling portions of the unissued shares, or, if it possesses no more unissued shares, by amending the certificate of incorporation so as to increase the capitalization. According to most continental statutes, however, the corporation does not come into existence before the whole capital stock is subscribed. ${ }^{\circ}$ Consequently, the raising of the needed capital can take place in only two ways: either during the process of the organization of the corporation, or by the increase of the capital stock after the creation of the corporation. The latter method, necessitating change in the articles of association, which fix the amount of the capital stock, ${ }^{10}$ is ordinarily available only when the original capital has been fully paid in. ${ }^{11}$ The third method, that of disposing from time to time of unissued shares to meet the need for capital, is, subject to a few exceptions, not open to continental corporations, because the continental legal systems do not recognize the distinction between authorized and outstanding capital. ${ }^{12}$

9. France: Law of July 24, 1867, 234 Bulletin des Lois 94, art. 1, 24; Germany: Handelsgesetzbuch (1897, 1931) \& 189; Switzerland: Obligationenrecht (1911) art. 618. The single phases of the founding process of a corporation under the continental laws aro the following: 1. drawing up of the articles of association. 2. subscription of shares. 3. payment of the first instalment on the subscription. 4. election of the board of directors and, in some countries, election of the board of supervisors. 5. filing of all important documents (including the articles of association and the subscription contracts) with a governmental body (in most states the judge in charge of the Commercial Register) and, in addition to the filing, in most states registration of the corporation in a commercial register and public announcement of the creation of the corporation. $2 \mathrm{~K}$. WritAND, HANDELSRECHT (1931) 52 et seq.; concerning the French law. See, however, stepra note -

10. See, for example, Belgium: Law of July 22, 1913, Moniteur July 25, 1913, art، 72; and Germany: Handelsgesetzbuch (1897, 1931) § 182.

11. Austria: Aktienregulattv $(1899,1925)$ § 31; Germany, Eandelsoesetzducir (1897, 1931) § 278; for further references see Haldsters, DiE Aktienrecite der Gequnwakt (1931) 183.

12. There is, however, a growing tendency to adopt this distinction. Sce, for example,

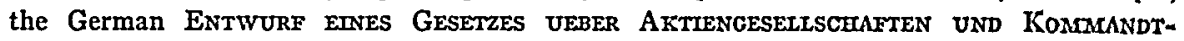


This difference in methods of capitalization has a direct bearing upon the scope as well as upon the mechanism of disclosure of information to investors. The continental protective systems must be differentiated according to the different groups of investors sought to be protected. The continental method of capitalizantion during the organizing of the corporation influences the provisions purporting to protect subscribers of the original capital stock, that is, investors who subscribe to the shares of stock before the corporation comes into existence, or, to be more accurate, before the filing of all the important documents, including the articles of association and the subscription contracts, and the registration or announcement of the creation of the corporation. ${ }^{13}$ Since the corporation has not yet come into being at the time of the subscription for the original capital stock and since the registration follows the subscription, the continental legislatures cannot make use of the "registration statement" as a device of disclosure to protect the subscriber to that stock. Therefore, the articles of association, being the certificate of incorporation and the by-laws all in one,$^{14}$ and being, except under the French law, ${ }^{14^{4 a}}$ drawn up before the capital stock is issued for subscription, play the role of the registration statement. In the United States, however, subscribers to the original capital stock can be protected by an exhaustive and detailed registration statement giving information about an already existent corporation, although, obviously, the registration statement of a newly founded corporation cannot answer all the questions contained in Schedule A.

While all the continental systems contain provisions relating to the disclosure of the articles of association, either requiring prospectuses or requiring other media of publicity, an estimate of the efficiency of these provisions must take into account a further peculiarity of the method of capitalization of continental corporations. There are two ways of capitalizing a continental corporation in organizing it: either the incorpora-

GESELISCHAFTEN AUF AKITEN (1930) § 157. At present a few statutes approach the distinction between authorized and issued capital to the extent that they allow the articles of association to confer upon the board of directors the power to increase the copital stock: up to a certain amount within a limited period, thus permitting the transfer from the meeting of shareholders to the board of directors of the power to increase the capital stod. As to the French law, see 2 HoupIN et Bosvieux, op. cit. supra note 7, n. 852; see further HALLSTEN, op. cit. supza note 11, at 81 .

13. In many countries the corporation comes into existence with its registration in the Commercial Register: (Germany) HANDELSGESETzBuch (1897, 1930) \& 200 (1); (Switzerland) ObligatronenRecht (1911) art. 623; in other countries it comes into existence upon the filing of the articles of association and the other neceseary documents with the proper local court, or with the filing with, and the publication by that court. Hurrstemr, op. cit. supra note 11 , at $145 ; 2 \mathrm{~K}$. Wresaiv, op. cit. supro note 9 , at 76 .

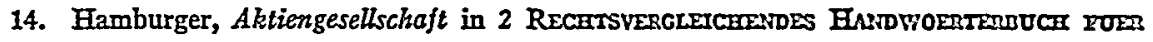
DAS ZIVIL= UND HANDELSRECET (1929) 59, 128.

14a. See infra note 43. 
tors subscribe the whole amount of the capital stock of the corporation simultaneously, or the capital is to be raised successively ${ }^{15}$ by way of public subscription. ${ }^{16}$ The corporation, however, comes into existence only after the whole capital stock has been subscribed. ${ }^{17}$

In most of the continental statutes the protective provisions are applicable only in the case of "successive subscriptions,"18 the theory being that the incorporators as insiders need not be protected in the same way as other subscribers. It is much the same idea which actuated the legislature of the United States to refrain from requiring a registration statement to be filed with the Securities Exchange Commission with reference to the preliminary negotiations between an issuer and an underwriter. ${ }^{10}$ But capitalization by successive subscription is not usual on the Con. tinent, ${ }^{20}$ since it subjects the incorporators to the risk that the public may fail to subscribe to the whole capital stock during the process of organization, and that thus the creation of the corporation may be prevented. Therefore the incorporators prefer the method of simultaneous subscription, which has the further advantage of being less complicated ${ }^{21}$ and of requiring less disclosure. But it would be wrong to assume that the financing of the corporation, from the standpoint of its incorporators, is finished with the creation of the corporation. In reality, this financing begins after its creation. Although the incorporators (original subscribers) have seemingly put at the disposal of the corporation the capital needed, not all of them-this is especially true for the investment banks

15. In subsequent reference to the different types of subscription the term "simultanrous subscription, although not accurate translation of the continental terminology used in the legal literature (Simultangruendung; the French expression is "fondation simultanece") will be used for purposes of convenience to refer to the situation when the entire sub. scription is made by the incorporators; and the term "successive subscription" (Successivgruendung; "fondation successive") will be used to refer to the situation when the incorporators subscribe for a part only of the stock, and the balance is subscribed by outsiders.

16. Though the French Corporation Statute of July 24, 1867, 234 Bulletin des Lois 94, mentions only the successive subscription and not the simultaneous subscription the latter is generally recognized by court decisions and text-writers. Thaller, Syndicats Financicrs d'Emission (1911) ANNares de Drotr Concurerctar 11.

17. 2 Lyon-Caen et Renault, Tratte de Droir Conorercial (1929) part 2, n. 6870.

18. A. Wieland, Die Apportgruendung der Aktiengesellschaft (1923) 42 ZnTscmRnt FUm SCEWEIZERISCHES RECHT 28a et seq.

19. Federal Securities Act $\S \S 2(3), 5,48$ Stat. 74,77 (1933), 15 U. S. C. A. $\$ \S 77 b$, 77e (1934).

20. A. Wieland, supra note 18, at 28a; Hallstein, op. cit. supra note 11, at 129; LxoNCaen et Revault, op. cit. supra note 17, n. 686; Tyaller-Percerov, Tratté ElEMentathe do Droir Comatrrctal (1925) n. 498.

21. In the case of a successive subscription during the organization of the corporation, two shareholders' meetings are necessary, one to elect the boards of directors and supervisors, and the other for resolving definitely upon the creation of the corporation. See for example Germany: HANDELSGESETZBUCE (1897) $\$ \$ 196,197$. In the case of a simultancous subscription these two shareholders' meetings are dispensed with. 
(Syndicats d'émission) which play an important role in corporation financing-have the intention of remaining permanently the sole shareholders. ${ }^{22}$ On the contrary, they intend to retain only a part of the stock they have subscribed, and to redistribute the rest as soon as possible, either by way of public offering or through the channels of the stock exchange, or, finally, by sales over the counter. ${ }^{23}$

In view of this situation, the efficiency of the continental systems is largely dependent upon the requirements of disclosure and the media of disclosure by which those systems attempt to protect the public at large, who buy from the original subscriber. Most of the legislatures

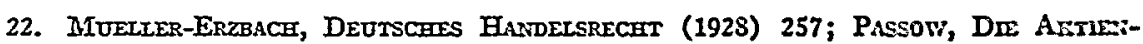
GESELISCHAFT (1922) 167; Thaller, supra note 16, at 11. It is usual to distinguish four different general methods of distribution of securities: The German method, also adopted in Switzerland, Austria and Hungary; the French method, also adopted in Belgium, Italy, Holland and Spain; the American method, and, finally, the English.

The English method differs more widely from the other ones than the latter do from each other. This was especially true up to the world war. But since that time, the English method has more and more approsched the other ones, which is eppecially due to the fact that the English national wealth, too, has decreased. The English method is characterized by the fact that the English enterprises can draw their capital from private capitalists connected with them. For this reason the issuance of shares by the enterpris? itself is more usual than the issuance through a selling syndicate or group. The distribution of the shares by the enterprise itself is nevertheless secured by underwriting agreements made between the issuer and the brokers who redistribute the shares and between the brokers and the financiers with whom they are connected. In contrast with the Englizh method all other methods possess the common feature that the shares are distributed by intermediaries, generally banks who are connected with each other by selling agreements of various kinds.

Under the German method, the parties to the selling agreement generally form a partnership which, although of temporary duration and limited in scope, has all the other characteristics of an ordinary partnership ("Einheitskonsortium," in contrast with the "Einzelkonsortium" or "Konsortialbeteiligung"). In most cases the investment banlis which form the selling agreement actually subscribe for the stock, rather than merely guarantea that subscribers will be found.

The main difference between the French and the German methods is that the members of the French "syndicats de finance," although substantially partners as between themselves, are presented by a single member (the so-called "gérant" or "banquier-cher") who alone incurs any legal liability with respect both to the issuer and to purchasers of the shares.

Thus in England, as a rule, we find the true underwriter who does not buy the stock but merely guaranties its sale; whereas, under the German and French systems, the intermediaries buy the stock outright and resell it.

The latter method prevails in the United States although the true underwriting is to be found occasionally, especially in particularly attractive issues. See Keichel, Emissionsgeschaeft in 3 RECHTSVERGLETCHENDE HANDWOERTERBUCH (1931) 41; Mílleromicz, Enis-

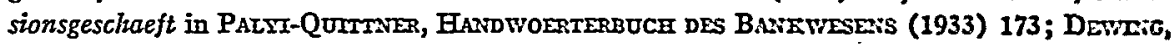
The Financtas Poltcy of Corporattons (3d ed. 1934) 980; Gatston, Secuntry Sxzutcatz Operatrons (2d ed. 1928); Thaller, suppa note 16, at 1 et seq.; Schmalenbach, Fria:zaresUNGEr (5th ed. 1932) 336 et seq.; for further references see infra, note 24.

23. Passow, op. cit. supra note 22, at 167 et seq.; Schornzernicr, op. cit. supro note 22, at 336 et seq. 
have not fully appreciated this situation, being of the opinion that the buying public is sufficiently protected by the publication of the articles of association, which has to be made after the registration of the corporation. But in the several countries where this publication is not usually required to contain as complete a disclosure as that required in the case of a "successive subscription," and where the media of disclosure applicable after the creation of the corporation are less effective than those applicable to the "successive subscription," the investor is insufficiently protected.

While the German and the French laws have recognized these dangers, they do not seem to have found adequate solutions. The French law, since the statute of $1907,{ }^{24}$ in this respect resembling the Securities Act, provides for the same disclosure requirements, whether the shares be publicly issued by the corporation itself to subscribers, or offered for sale to the public by incorporators, especially "syndicats de finance," the French counterpart of underwriters. ${ }^{25}$ Furthermore, it prohibits the negotiation of all shares received in exchange for property until two years after the registration. ${ }^{26}$ The German law has found a quite different solution. It attempts to protect the investing pubic in a twofold manner: first, it has introduced safeguards for the protection of all investors, especially to prevent overvaluations of property transferred to the corporation in exchange for shares, and prescribes that these safeguards shall be applicable whether the capitalization takes place in the form of a simultaneous subscription or of a successive subscription..$^{27}$ Second, on the theory that the original incorporators will normally list their stock on the stock exchange in order to redistribute the shares, ${ }^{28}$ the German Stock Exchange Law (Boersengesetz) of 1896 has safeguarded very strongly this channel of distribution in order to protect the investor, but has neglected the other channels for distribution. Unfortunately, the idea with which the German legislature started was wrong from the beginning, as Max Weber pointed out forty years ago in his famous articles ${ }^{20}$ criticizing the draft of the Stock Exchange statute. For the drastic list-

24. E. Wahl, De la Publicité des Placements de Titres Suivant la Loi du 30.1.1907 (1907) J. DEs Soctétés 195, 241; 2 HoupIN et Bosvieux, op. cit. supra note 7, n. 1800 et seq.

25. As to "syndicats de finance" see: Thaller, supra note 16, at 1, 83; YvES-LE ROY, Les SyndicaTs D'EMTSSION (Paris thesis of 1914); TharleR-PERCEROU, op. cit. supra noto 20, n. 498; 2 Pic. Des Sociétés Comanerciares (2d ed. 1925) n. 955; Angeloni, Sindichti Finavziari (1909).

26. See infra page 1150.

27. Germany: HaNdeISGESETZBUCH $(1897,1931) \S 186$.

28. BERICHT DER BOERSENGESTZKOMOMTSSTON (1893) 74.

29. Max Weber, Die Ergebnisse der deutschen Boersenenquete (1894) 44 Zeitschrift FUER HANDELSRECET 1 ; (1895) 45 id. at 72. 
ing requirements have increased the temptation of many incorporators to use other channels for the distribution of stock..$^{\text {:0 }}$

The result is that the German protective system, viewed as a whole, is not very well balanced. In this respect, the superiority of the American protective system over the German is evident, since the American legislature has made the requirements in the Securities Act fully as stringent as those demanded under the Securities Exchange Act, thus protecting all purchasers of the stock in original issues falling within the scope of the Act, as well as purchasers of listed securities resold on the exchanges. This lack of harmony of the German law operates particularly to the detriment of all buyers of unlisted stock who acquire stock distributed after the registration of the corporation which takes place after the entire capital stock has been subscribed, but before the end of the first fiscal year of the new corporation. After the end of the first fiscal year, the buyers are protected by the publication of the balance sheets and the profit and loss statements, as will be later shown. ${ }^{31}$ Those investors who buy unlisted stock prior to this time are protected only by the requirement that the corporation disclose the articles of association, and, if property other than cash has been taken over by the corporation during the founding process, by the further requirement that an impartial examination of the adequacy of the valuation of the property thus transferred must take place. But this latter requirement is not very well safeguarded against easy evasion. ${ }^{32}$ This means that these investors are much less protected than buyers of listed stock. The discrepancy between the kinds of protection afforded to the two groups of investors not only appears in the difference in disclosure requirements, but also in two other respects: first, the investor in unlisted stock before the end of the first fiscal year of the corporation is not safeguarded against the danger that the financial success of the corporation may be bad from the beginning, as is the buyer of listed stock, to some extent on account of the fact that the listing committee of the stock exchange has the power to reject the application for listing the stock of financially unsound enterprises. ${ }^{33}$ Furthermore, the investor in the unlisted stock of a corporation before the end of its first fiscal year, where that corporation has been created by incorporating an already existent enterprise, other than a corporation, is not fully protected against the danger that the financial basis of the corporation is unsound on account of the overvaluation of assets. This danger does not menace an investor who buys only listed stock of the latter type of corporation, for the reason that such stock can be officially traded in only after the lapse of the so-called "Sperrjahr," that is, one year after the

30. Goeppert, Probleme der Prospekthaftung (1935) 24 Barzuscinv 68.

31. See infra page 1152.

32. See infra page 1151.

33. Germany: Bozrsentgesetz (1896, 1908) § 36 . 
registration and after the first publication of a balance sheet and profit and loss statement. ${ }^{34}$

Through these various regulations, the German law has broadened the natural gulf between the type of protection afforded to those investors who buy unlisted stock prior to the publication of the profit and loss statement and balance sheet for the first fiscal year and that afforded to those investors, in both listed and unlisted stock, including subscribers to increases in capital stock, who buy afterwards, to the detriment of the buyer who belongs to the former group. The latter group of investors is protected not only by the required disclosure of the articles of association, but, what is even more important by the required periodical publication of the balance sheets and profit and loss statements. ${ }^{35}$ This is true for all continental legal systems, but has been of especial importance for the German law since 1931, when the law was altered in order to approximate the disclosure requirements relating to the profit and loss statements and balance sheets of all corporations to the stringent rules which the Listing Committee of the Berlin Stock Exchange had laid down for corporations with listed stock. ${ }^{36}$

There remains a last principal difference between the Securities Act on the one hand, and the continental statutes, on the other, namely, the fact that there is no counterpart in the continental legal systems to the Securities Exchange Commission, with its power to investigate alleged viola. tions of the Act, ${ }^{37}$ to issue stop orders, and to make rules and regulations, including those governing registration statements and prospectuses. ${ }^{30}$ Either the fulfillment of the disclosure requirements is safeguarded only by penal provisions, as in France, ${ }^{30}$ or is very insufficiently watched by the judge in charge of the Commercial Register, as in Germany. ${ }^{40}$ This

34. Id. $\$ 47$.

35. See infra page 1152 .

36. Law of September 19, 1931, Reichegesetzblatt I 493.

37. Comment (1935) 44 YaLe L. J. 819.

38. $\S 8,19,20,21,22$.

39. 2 Pic, op. cit. supra note 25, n. 1078. As to the defects of the French system, see further Thaller, supra note 16 , at 91 .

40. "The judge in charge of the Commercial Register is solely under a duty to see to it that the incorporators petitioning for registration of the corporation have filcd in at least outwardly proper form the necessary articles of association, subscription contracts, contracts for the transfer of property other than cash to the corporation and the reports of the boards of directors and supervisors and of the appraisers with respect to such transactions, documents relating to the appointment of the members of the board of supervisors (which is done by the shareholders at a shareholders' meeting) and of the members of the board of directors (which is done either by the board of supervisors, or by the shareholders at a shareholders' meeting), and finally a signed statement by the incorporators and the members of the boards of directors and supervisors to the effect that at least one-fourth of the par value of every share of capital stock has been paid into the corporation. HandetcesetzBucr $(1897,1931) \S 195$. While the judge is cmpowered to investigate the truth of the statements filed, if he so desires, he is under no duty to do so and usually does not. See further infra note 56. 
lack of a competent authority has prevented the continental legislatures from making the rules governing disclosure as flexible as is done in the Securities Act by allowing the Securities Exchange Commission to adjust the "registration statement and prospectus to the needs and requirements of various situations." 41

We are now prepared to discuss the details of the various protective systems, and we will deal first with the protection by disclosure of information important to the investor.

\section{II}

\section{Disclosure and its mechanism}

A few general remarks may be permitted as an introduction. The Securities Act has created for the protection of the investor a uniform mechanism of disclosure which must be used wherever shares are ofiered to the public: a registration statement and a prospectus giving detailed information. The continental systems have solved the problem of protecting the investor quite differently. First, as to the scope of publicity, most of the legal systems by no means go so far as the Securities Act. Second, instead of the uniform disclosure mechanism used by the Securities Act they have a mosaic of disclosure mechanisms. ${ }^{42}$ The most important part of this mosaic is the articles of association, which constitute the foundation stone upon which the whole system of protection by disclosure rests. The information they contain is always brought up to date by the fact that all alterations of the articles of association, especially increases of stock, as well as the yearly profit and loss statements and balance sheets, must be filed with the local judge in charge of the commercial register and published in official newspapers. Since all this information is a matter of central public record and publication in most countries, instead of local record and publication as is the case in the several American states, the majority of the continental countries do not feel the necessity of requiring the same coherent disclosure mechanism demanded by the federal government under the Securities Act.

\section{The Articles of Association}

The articles of association afford the most important mechanism for giving information to the original subscriber, the subscriber to increased capital, as well as to the buyer of securities resold by the incorporators. Its minimum contents are prescribed by the statutes. The French law is an apparent exception to this fundamental rule, having no explicit compul-

41. Douglas and Bates, The Federal Secturities Act of 1933 (1933) 43 Yare L. J. 171, 213.

42. France and Belgium do not belong to this group, their statutes being securitis acts, or to be more accurate, securities and securities exchange acts all in one. 
sory requirements relating to the articles of association. However, the required minimum contents can be deduced a fortiori from the prescribed minimum contents of the "notice" to be advertised in the "journal officiel" before any public issuance of the stock can take place. ${ }^{43}$ The facts which must be disclosed by the articles of association, which must be signed by the incorporators, ${ }^{44}$ can be grouped as follows: First, they must contain all the facts which individualize the corporation; into this group belong statements as to the name, the seat of its principal office, and the object of the corporation and its organization. ${ }^{45}$ Second, they must contain information concerning the capital structure of the corporation, the amount of the capital stock and of the number of shares. ${ }^{40}$ In those legal systems which distinguish between bearer shares and shares naming the shareholder disclosure of information as to whether the shares to be issued shall be bearer or "named issuee" shares is required. ${ }^{47}$ In addition to this disclosure many of the legal systems require publicity as to the preferences of individual shares or classes of shares. ${ }^{48}$ These requirements have the same function as sections $1,8,9,11$ of Schedule $A$

43. The Statute of January 30,1907, 405 Bulletin des Lois 1433, which contains this provision is of the greatest importance for the protection of those investors who subscribe to shares during the process of organization. The fact that the Corporation Statute of 1867 does not fix an exact date for the drawing up of the articles of association subjected these investors to considerable risk, until the Law of 1907 was enacted. Since the Corpora. tion Statute of 1867 does not require the publication of the articles of association untll after the creation of the corporation, there are under this Statute no disclosure requircments for the protection of the subscriber to the original capital stock. The Statute of 1907 has improved the situation insofar as it fills the gap left open by the Corporation Statute of 1867 ; but it fulfills this task inadequately. 2 LYON-GAEN et RENAUt, op. cit. supra note 17 , part 2, n. 770 .

44. Germany: Handeiscesetzbuch $(1897,1931)$ \& 182; Switzerland, Ophigatronenrecut (1911) art. 615.

45. France: Law of January 30, 1907, 405 BULletro DEs Lors 1433 art. 3; Germany: HANDEISGESETZBUCH (1897) § 182 .

46. France: Law of January 30, 1907, 405 BuLLETTN DES Lors 1433, art. 3; Germany: HANDETSGESETZBUCH (1897) § 182; Switzerland, ObijGATTONENRECHT (1911) art. 616.

47. Germany: Handeisgesetzbuch (1897) § 183; Italy: Codice di Consercio (1882) art. 89 (4); Switzerland: OBLIGATTONENRECHT (1911) art. 616 (5).

The continental legal systems recognize not only "named issuee shares" but, following the French example, bearer shares as well. Concerning the legal nature of the former, the various legal systems differ widely. According to $\$ 222$ of the German HANDELSOESETzBUCH, the named issuee shares are negotiable like bills and notes in the sense that $\mathfrak{a}$ bona fide purchaser can acquire 'a good title on the instruments by indorsement, even if the seller has no title. A transfer on the books of the corporation is necessary only to legitimate the indorsee as against the corporation. Under the French system, a transfer on the books of the corporation is necessary to make a transfer valid as against third parties as well as the corporation.

As regards bearer shares many legal systems allow their issuance only if the whole subscription has been paid in.

48. Germany: Handelsgesetzbuch $(1897,1931) \S 185$. 
of the Securities Act. Finally, the continental statutes seek through disclosure in the articles of association to protect the investor against the watering of capital stock, ${ }^{49}$ in those cases where the corporation is organized by the transformation of an existent enterprise (single enterprise or partnership) into a corporation through the issuance of shares of capital stock to the former owners of the transformed enterprise in exchange for their property or proportionate interest therein, or where the contribution of subscribers in exchange for capital stock consists in transfers of tangible or intangible property other than cash (especially patent rights) to the corporation. The victims of a failure of a corporation due to overvaluation of property are usually not those persons who have made the transfers of property for capital stock, because they very quickly get rid of their stock, but, rather, all other subscribers who have paid in cash, and who, as outsiders, have not an accurate knowledge of the unsound capital structure of the corporation. To meet these dangers, most of the continental statutes prescribe that if the articles of association do not disclose such transactions, the corporation is not bound to the persons who received shares in exchange for the transfer of property. But required methods of disclosure of such transactions differ widely under the various statutes. The older type of legislation, represented by the French law, requires only a summary description of the assets and of the number of shares allotted to the vendors of the assets as consideration for the transfer of the assets to the corporation. ${ }^{50}$ The newer type of legislation, represented by the German law, goes a good deal further by requiring detailed disclosure of the particular types of property making up the total assets other than cash transferred for the shares, the names of the transferors and the principles of valuation used. Many statutes ${ }^{51}$ extend the same disclosure requirements to transactions by which the corporation, during the process of organization, acquires property from an incorporator or from a third person for cash, since absence of such additional requirements might easily lead to the frustration of the purpose of the rules requiring disclosure of all agreements relating to transfers of property in exchange for shares. ${ }^{52}$

49. Germany: HaNdersGeserzbuch $(1897,1931)$ § 186(2); France: Lar of 30.1.1907, 405 BULIETIN DES LOIS 1433, art. 3.

50. A. Wieland, supra note 18, at 313; Germany, HaxdersGesetzsucr, $\$ 186$ (2).

51. Austria: AzTIENREgULATT (1899, 1925) $\S \S 7,20$; Germany: HardoersgesetzLECT (1897, 1931) § 186(2); Switzerland: ObLrGatrontenrectr (1911) art. 619. The French law has no provisions relating to transfers of property other than cash in exchange for cash during the founding process. The French courts (Tribunal de Commerce de la Saine of December 12, 1892, 1893, J. Des Soctétés 108; Tribunal de Commerce de la Saine of July 23, 1894, Recueil Sirey 1895 II 105) and the French textwriters (Houpri-Bosurwar, op. cit. supra note 7, n. 720) deny, therefore, that such traneactions bind the corporation.

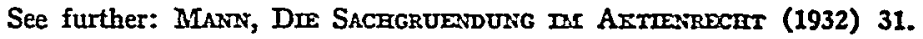

52. A. Wieland, supra note 18 , at $31 a$. 
In Germany, these provisions failed to a large extent, ${ }^{63}$ since incorporators often evaded them by purporting to pay for the capital stock in cash, but, in accordance with a previous secret agreement made during its organization, transferring the contemplated property, instead of the cash, to the corporation as soon as it was registered. ${ }^{54}$ To meet this danger, the German law prescribes that all transactions concerning transfers of plants and structures, or of immovables worth more than one tenth of the capital stock, made during the first two years after the registration of the corporation, must be ratified by a qualified majority of shareholders. ${ }^{55}$ However, this provision may fail to protect the subscribers, since the persons interested in such transfers usually have enough shares to control the votes during the statutory period..$^{60}$

In addition to the above disclosure requirements, some statutes, regarding every agreement conferring special advantages on any incorporator as potentially dangerous to investors, require disclosure of all such agreements in the articles of association. ${ }^{57}$ A few statutes go still a step further by requiring that the amount of the organization expenses borne by the corporation must be disclosed. ${ }^{58}$

It is necessary at this point to compare the media adopted under the Securities Act and under the various continental statutes for the disclosure of the information given in the first case in the registration statement, and in the second, in the articles of association.

The registration statement under the Securities Act is made available to the investor in three ways: (1) it is subject to examination by the public, (2) the Securities and Exchange Commission must furnish photostatic copies to all applicants for a reasonable charge, (3) the issuer must prepare a prospectus summarizing the registration statement. ${ }^{50}$ The disclosure mechanisms used in the various continental countries are differ-

53. This has been admitted by many competent writers: MUELLER-ERzDACH, op. cit. supra note 22, at 267; Schmalenbach, op. cit. supra note 23.

54. See the citations in the note 53, supra.

55. Germany: HANDEISGESETzBUCH $(1897,1931) \S 207$.

56. MUELLER-ERzBACH, op. cit. supra note 22, at 264. The temptation to use this method will no longer exist if $\S 36$ of the ENTwURF EINES Gesetzes UEder AKTIENGESELLCHAFTEN UND KONOMANDITGESELLSCEAFTEN AUF AKTIEN becomes law, becauso this paragraph extends the disclosure requirements and other safeguards to this sort of transaction. While under the present law there exists an additional safeguard in that the judgo in charge of the Commercial Register has the power to reject the application for registration in cases of evasion and, what could be more important, the power to investigate whether or not an evasion has taken place. Nevertheless, this theoretical power has not hindered many evasions. MUELlER-ERzBACH, op. cit. supra note 22, at 264.

57. Germany: HANdeisGesetzbuch $(1897,1931)$ \& 186; Italy: Codice dr Conmurcio (1882) art. 89.

58. Germany: HaNdetsGesetzBdCH $(1897,1931)$ \& 186. This provision has resulted in the incorporators paying all these expenses. Passow, op. cit. supra note 22, at 109.

59. $\S \S 5,16$. 
ent. This is partly due to the difference in methods of organization of corporations on the continent and in the United States. ${ }^{c 0}$ Thus, while the registration of a continental corporation by the filing of its articles of association with a governmental body (usually the judge in charge of the commercial register) is a procedure which parallels the filing of the registration statement by an American corporation to the extent that the filing in both cases takes place after the organization of the corporation, nevertheless it would not be sufficient to perform the function performed by the registration statement under the Securities Act. For, since the continental corporation is not fully organized until the sale of its capital stock, so that the registration can only take place after that sale, the information disclosed at the time of registration would fail to protect purchasers of the capital stock.

The disclosure of the articles of association under continental law, however, is only intended to protect investors other than the incorporators, since the latter are largely protected in the process of formation by their inside knowledge. The former type of investors are protected under a number of continental systems by the requirement that, before public offerings of shares for subscription may be made, either the articles of association, or, what is the same, the essential information with respect to the corporation must be published in official newspapers. This system prevails, for example, in France and Belgium. ${ }^{01}$ According to the French law, every public solicitation to subscribe, for example, a prospectus or an advertisement in newspapers, must repeat the disclosures, referring to the number of the journal officiel in which the original information was published. ${ }^{62}$ A similar mechanism of disclosure prevails in all those countries which require that a public solicitation to subscribe has to be made in the form of a prospectus. Such a prospectus must contain the articles of association, at least in a condensed and summarized form, and very often, in addition to it, information relating to the terms of subscription and payment. ${ }^{.3}$ According to this system which is. for example, in existence in Italy, Portugal, Poland, Switzerland and Hungary, ${ }^{64}$ a general publication of the prospectus is sufficient. Contrary to the provisions of the Securities Act, it need not be handed over or sent

60. See supra page 1136 et seq.

61. Belgium: Law of July 22, 1913, Moniteur July 25, 1913, art. 32(2); France: Law of January $30,1907,405$ Bulletin des Louis 1433, art. 3. In case of noncompliance with this prescription, the subscription is nevertheless binding. 2 Ixox-CaEx et Remour, op. cit. supra note 17 , part 2, n. 687 b.

62. 2 PIC, op. cit. supra note 25, n. 1079.

63. Haristenn, op. cit. silpra note 11 , at 133 .

64. Italy: Codice or Conarencio (1882) art. 129; Switzerland: Buronerarsoneconacs

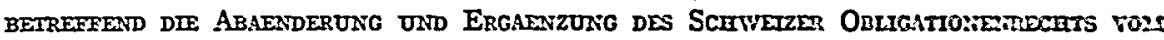

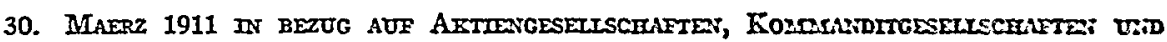

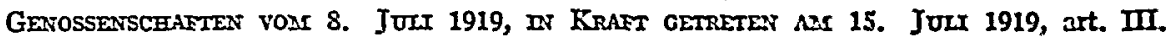


to the individual prospective buyer of the shares. ${ }^{65}$ The requirement under the laws of several continental countries that the articles of association must be filed with a governmental body (usually the judge in charge of the commercial register) affords no protection to the group of investors here discussed, because the filing takes place at the end of the organization of the corporation, and therefore, after the subscription to the entire capital stock has been made.

While some statutes, such as the Securities Act, ${ }^{80}$ allow private solicitation without publicity, requiring publication of the articles of association or a prospectus only in the case of public subscriptions, other statutes are more rigorous in effect, for the reason that they allow only public subscriptions. ${ }^{67}$ The latter system is represented, for example, by Italy and Switzerland. A continental representative of the group to which the Securities Act belongs is France. ${ }^{68}$ Due to the fact that the French statute is very poorly drafted, ${ }^{69}$ there are in France many controversies concerning the question of whether a particular solicitation is public, rather than private, and whether the publication requirements are therefore, applicable. It is now admitted ${ }^{70}$ that an offering is public not only given in the case of an offer to subscribe made to the public at large, but also in the case of an offer made to a large group of the public. ${ }^{71} \mathrm{Ac}$ cording to this interpretation of the Statute, the required "notice" with its information must be published if the corporation intends to distribute its shares over its counter. On the other hand, the Statute is inapplicable, if the shares are offered without any public advertisement. If the solicitation is admittedly public in nature, however it seems settled that the publication requirements are not only applicable when the public offering is made by the corporation itself, but also, when the shares are offered by or through another person. ${ }^{72}$ For, it is one of the main purposes of the French act that the disclosure requirements should be applicable when the shares are to be distributed by "syndicats de finance, ${ }^{\prime 73}$ the French counterparts to the American underwriters, as defined by the Securities Act.

\footnotetext{
65. $\S 55(2), 2(10)$.

66. $\$ \S 5,4(1)$.

67. See the citations in note 64 , supra.

68. 2 PIC, op. cit. supra note 25, at n. 1079.

69. Thaller, supra note 16 at page 7 .

70. 2 Houpin et Bosvieux, op. cit. supra note 7, at n. 1801, 1803 n. 1; 2 Lyon-Cands et RENAULT, op. cit. supra note 17 , part 2 , n. 687 c.

71. For the English definition of public offering, see Nash v. Lynde [1929] A. C. 158, 171, 185; American: Douglas and Bates, supra note 41, at 185.

72. Correctional Tribunal Seine, June 4, 1913 (1914) J. des Sociétés 37; Datloz JurusPRUDENCE 1914 II 121, annotated by Chéron; 2 Houper et Bosvieux, op. cit. supra note 7, at n. 1803.

73. Supra note 22 .
} 
The publication of the "notice" in the journal officiel takes place prior to the offering of the capital stock for subscription. ${ }^{74}$ If the shares are taken by a selling syndicate for the redistribution of shares, the publication of the "notice" is not necessary, as long as this syndicate does not offer the shares to the public. ${ }^{\text {T5 }}$

All these methods of disclosure suffer from a very serious defect in that the protection they afford to the subscriber is incomplete to the extent that they confine themselves to a mechanism of general publicity. This defect has been remedied by various of the continental legal systems. Their remedies have in common the quality of affording to the subscriber the possibility of becoming acquainted with all the essential facts concerning the corporation. In this group belong legal systems which, like the Finnish, ${ }^{76}$ require that the names of the subscribers and the amounts of their subscription must be disclosed in the articles of association or in a copy of them, or which, like the Danish, ${ }^{77}$ require that the subscribers fill out their names and the amount of their subscriptions on the corporation's subscription list, at the top of which is a copy of the articles of association. In this group belong, further, all statutes which demand that the subscription contract must restate the contents of the prospectus. Such is the law in Norway, Sweden, Hungary, Bulgaria, and Poland.3 To this list must finally be added the German, Swiss and Belgian laws, which require that the subscription contract must be incorporated in a subscription slip, the latter disclosing all the essential facts, particularly, the corporation's articles of association. ${ }^{70}$

\section{Additional Disclosure Requirements}

The description of the system of publicity for the protection of the investor would be very incomplete if the disclosure provisions in addition to those requiring the disclosure of the articles of association were overlooked.

As a result of unfortunate experiences of investors, all continental countries include in their corporation statutes special provisions relating to the type of corporate financing in which property other than cash is

\footnotetext{
74. 2 PIC, op. cit. supra note 25 , at n. 1078.

75. Ibid.

76. HACISTEIN, op. cit. supra note 11, at 134, n. 76.

77. Law of April 19, 1933, Lovimberdew A Nr. 18. vom 19 April 1930 S. 663-637, \& 10.

78. HaLISTEN, op. cit. supra note 11, at 133.

79. Germany: HaNdersGesetzBUCH (1897, 1931) \& 189.

The German Law, though not requiring a prospectus unless an application for listing on the Stock Exchange has been made, provides that where a banking house voluntarily publishes a prospectus which contains untruths, it is liable to the corporation for such untruths unless they are made in good faith. $\S 203$. In the case of a public solicitation to subscribe, the publication of a prospectus is usual. The liabilities for untrue prospacturs under $\S 45$ of the German Stock Exchange law protect the individual purchaser.
} 
taken in exchange for shares. ${ }^{80}$ We can distinguish an older type of regulation represented by the French law and a newer one represented by the German law. ${ }^{81}$ According to the French law, and those legal systems which follow the French pattern ${ }^{82}$ it is not sufficient that the property received by the corporation in exchange for shares and the "avantages particuliers" (for example "parts de fondateur ou parts beneficiaires") ${ }^{\text {s3 }}$ obtained by the transferrors of the property are described and the number of shares given in exchange disclosed in the articles of association. In addition, it is required that the transactions be ratified at two meetings of shareholders held subsequent to the disclosure of this information in the articles of association, and that, for this purpose, the transactions be disclosed in a more detailed manner to the shareholders. At the first of these meetings, the shareholders cannot ratify the transactions, but are limited to electing auditors (the so-called "commissaires aux apports"), to verify their validity. In less complicated cases, the shareholders themselves may make the verification. Final approval of the transactions by the shareholders may be given at the second meeting, but, in the cases where the shareholders have not themselves made the verification, only if a printed report of the auditors' verification has been made available to every shareholder at least five days prior to the meeting. Shareholders, who are also vendors of the property involved in such transactions, have no voting rights at these meetings. ${ }^{84}$ According to the judicial interpretation of all these provisions, they are not applicable in the case where the incorporators have purchased the entire capital stock. ${ }^{80}$ But even where applicable, they have entirely failed their purpose, either because the auditors ("commissaires") are mere instruments in the hands of the incorporators, or because they are incompetent. ${ }^{86}$

A French statute of 1893 , which has been copied in many countries, ${ }^{87}$ has been no more successful. Its provisions contain no disclosure requirements, but seek only to strengthen them. This statute prohibits the negotiation of all shares (the so-called "action d'apport") received in exchange for transfers of property other than cash within two years after the registration of the corporation. To make this provision effective, the

80. 2 PIC, op. cit. supra note 25 , at n. 919.

81. 2 K. WIELAND, HANDELSRECET (1931) 64 et seq.

82. France: Corporation Statute of July 24, 1867, 234 BuLLETIN DEs Lors 94, art. 4; Italy: Codtce or COMnarercto (1882) art. 130, 135 (1) (2); Switzerland: OntrontronenRECHT (1911) art. 619.

83. These "parts" cannot be likened to the founders' shares of the English law, because the "parts" do not form part of the capital of the corporation as do the founders' shares, but, rather, give merely a right to share in profits.

84. 2 Prc, op. cit. supra note 25, n. $92 \mathrm{i}$ et seq.

85. A. Wieland, supra note 18 at $8 \mathrm{a}$.

86. 2 PIc, op. cit. supra note 25 , at 954 .

87. $2 \mathrm{~K}$. WIELAND, op. cit. supra note 81 , at 64 n. 3. 
Statute prescribes that the directors of the corporation must stamp the "action d'apport" with an indication of its nature and the date of the formation of the corporation. The statute prohibits only the "negotiation" of shares, that is, delivery or indorsement; it leaves open the possibility of an assignment according to the principles established in article 1690 of the Code Civil..$^{88}$ Further, the incorporators evaded the restrictions on negotiations of such shares by using other devices, for example the "parts beneficiaires," instead of "actions d'apport." To check this evasion a Statute of 1927 extended the restriction relating to the negotiability of the "actions d'apport" to all other types of shares resorted to for the purpose of evading the law. ${ }^{30}$

The other type of regulation, represented by the German law, requires the incorporators to make a written report regarding such transfers. ${ }^{\text {II }}$ The transactions must also be investigated and reported by the boards of directors and of supervisors of the corporation ${ }^{92}$ and, finally, by at least two appraisers. ${ }^{93}$ These appraisers are nominated either by the competent local Chamber of Commerce, or, if there is none, by the judge in charge of the Commercial Register. ${ }^{9 \pm}$ Opinion regarding the efficacy of the German appraisal system differs widely. While some authorities in France propose copying the German provisions, ${ }^{95}$ the most competent writers on German corporation law admit that these provisions do not work as well as has been expected. One result of these provisions seems to be clear; they have increased ${ }^{96}$ the temptation to conceal from the judge in charge of the Commercial Register the fact that property other than cash has been transferred to the corporation in exchange for shares during its organization process. Furthermore, the incorporators make their report as meaningless as possible, in order to avoid any liability on account of an untrue report. ${ }^{97}$ The reports of the appraisers are defective, too, according to Passow, a very reliable writer. According to him, it is very often astonishing how little the reports go into details. ${ }^{99}$ This usage diminishes to a large extent the validity of the theory that

88. Thatcer-Percerou, op. cit. supra note $20, \mathrm{n}$.

89. Sispra note 83 .

90. 2 Lyon-Caen et Renaut, op. cit. supra note 17, part 2, n. 635.

91. Germany: Handelsgesetzbuch (1897, 1937) § 191. This report of the incorporators must contain a detailed disclosure of (a) the terms of the purchase contract batreen the transferor of the property and the corporation, (b) the terms of any contracts previously entered into by the transferor and a third party, by means of which the tranziferor originally acquired the property, (c) the cost and the reproduction values of the profarty; whether or not these values are reported as identical, (d) the earnings on the proparty for the two preceding fiscal years, where the property transferred consists of an entire business enterprise.

92. Id. § $192(1)$.

94. Id. $\S 192$.

96. Sucpra note -

98. Op. cit. supra note 22, at 123.
93. Id. § 192 (2).

95. 2 Prc, op. cit. supra note 25, n. 955.

97. A. Wielnnd, stupra note 18 , at 403 . 
the investors are protected by the fact that everybody can look into the reports which have to be deposited with the court in charge of commercial matters as well as with the Chamber of Commerce..$^{00}$ The main defect of the German law as it stands is that the judge in charge of the commercial register is under no legal duty to reject the application for registration, even if the report of the appraisers is unfavorable, showing, for example, that overvaluation of property has taken place. ${ }^{100}$ Nevertheless, the German rules are not without any merits. Their importance does not lie so much in the fact that the reports can be inspected, but is an indirect one. For the possibility of the appraisers' objecting to the validity of the transactions involving overvaluation of assets very often hinders the incorporators from entering into them. ${ }^{101}$

We have been dealing until now with the disclosure mechanisms closely connected with the founding of the corporation, protecting especially those investors buying, either during the process of founding or shortly afterwards, stock forming part of the original capital stock. We turn now to the methods used by the continental legal systems to keep the basic information contained in the articles of association up to date in the interests of subsequent investors. This is done first by the prescription that all alterations of the articles of association ${ }^{102}$ must be filed and registered with the judge in charge of the Commercial Register and published in official newspapers; ${ }^{103}$ then, by the requirement of periodical publication, concerning the financial status of the corporation. ${ }^{104}$ The details of these rules, that is, the regulations concerning the contents of the balance sheets and profit and loss statements, the periods of publicttion and the mechanism of publication differ widely. The German Commercial Code, since the Statute (Verordnung) of September 19, 1931,105 contains very detailed provisions concerning the minimum contents of the required balance sheets and profit and loss statements. It demands, further, that the balance sheets and profit and loss statements shall be supplemented by a written report of the board of directors concerning the financial situation of the corporation. This report must clearly explain the items in the balance sheets and profit and loss statements, and

99. Germany: HaNdexSGESETZBUCH (1897, 1930) §§ 195 (5), 199.

100. 2 StAUb-Pinner, Komomentar zon HANdetsgesetzbuct (14th ed. 1933) \& 193, Ann. 6. This defect will no longer exist if $\S 17$ of the Entwurf Ennes Gesetzes vum AKTIENGESELISCHAFTEN UND KoMMNUNDITGESELLSCHAFTEN AUF AKITIEN (1930) becomes law.

101. PAssow, op. cit. supra note 22, at 123.

102. Only a shareholders' meeting is competent to alter the articles of association under most statutes. HALISTEIN, op. cit. supra note 11, 177.

103. Germany: HANDELSGesetzbucr $(1897,1937) \S 277$; Switzerland: OblicationeNRECHT (1911) art. 626.

104. Hatistets, op. cit. supra note 11, at 186.

105. Germany: FANDETSGeSETZBUCH $(1897,1937) \S 260$ et seq. 
contain disclosures relating to events of special importance occurring subsequent to the fiscal year. The report must disclose the business relations existing between the corporation and any subsidiary or affiliated company and between it and any other corporation with which it has a pooling agreement. The latter disclosure requirement includes contracts with such other corporation, relating to supplies of merchandise, financing, leases and the like. The report must further indicate the degree of the financial interest in such other corporation or corporations, inclusive of credits and guaranteeships, as well as any duty it may be under to render further financial assistance. In addition to the above, the report must, among other information, contain disclosures relating to shares of the corporation repurchased and held as treasury shares, or shares sold originally to third persons closely connected with the corporation and held by such persons "for the account of" the corporation, shares transferrable only with the permission of the corporation, and which usually have extraordinary voting privileges, bonuses, any liabilities which are not ascertainable from the balance sheets, the total amounts of salaries received by members of the boards of directors and of supervisors, given separately according to whether the salary is received as a member of one type of board or of the other. The report must be made according to the principles of good faith required for an accounting. Disclosures may be omitted only to the extent that may be demanded by the "preponderant" interests of the corporation or of any corporation with which it may be associated or of the public.

Although the annual report of the board of directors need not be made public through the newspapers, as do the balance sheets, but need only be filed with the judge in charge of the Commercial Register, nevertheless, the information it contains reaches the investor through the channels of the financial newspapers.

The balance sheets and profit and loss statements prepared under the direction of the board of directors are submitted to the shareholders for their approval at a shareholders' meeting. In addition to approval, the shareholders must at this meeting vote whether or not to discharge the directors from liability to the corporation for damages resulting from any misleading or false statements or omissions in the balance sheet and profit and loss statement, and, in addition, for any damages which may have been caused during the accounting period by the mistakes of the management. Before the balance sheets and the profit and loss statements are handed over to the shareholders to be approved in a shareholders' meeting they must be verified and examined by one or more accountants who were appointed either by a vote of the shareholders in a shareholders' meeting prior to the end of the fiscal year or by the board of directors or of supervisors. ${ }^{100}$ 
These provisions do not, however, afford full protection to the investor. For, if the shareholders approve a balance sheet and a profit and loss statement which fail to comply with the statutory schedule, this approval cannot be attacked like other defective resolutions in a shareholders' meeting. ${ }^{107}$ The only possible safeguard against failure of compliance is the fact that accountants must examine and verify the balance sheet and profit and loss statement, but even this safeguard may be evaded if neither the shareholders nor the board of directors or supervisors elect accountants. ${ }^{108}$ But an even more serious source of danger to the investor may be found in the fact that disclosures may be omitted to the extent that may be demanded by the "preponderant interests" of the corporation, or any corporation with which it may be associated or of the public. 'This possible exemption from the disclosure requirements gives the board of directors a means of legally withholding from the public many vital facts. ${ }^{109}$

To complete the mosaic of the disclosure requirements built up in the continental legal systems for the protection of the investor, we have only to describe the disclosure mechanisms connected with the increase of the original capital stock by the issuance of new shares. The disclosure system developed in the interest of the subscriber and buyer of an increase in capital stock in most legal systems is modeled according to the pattern used to protect the subscriber of shares of the original capital stock, but adapted to the changed situation. ${ }^{110}$ Thus, those statutes which require disclosure through a prospectus in the case of the original issue, also require a prospectus in the case of an issuance of shares of the increased capital stock. ${ }^{111}$ The prescriptions concerning the minimum content of the latter type of prospectus take into account that the issuer is a going concern with a financial history. For this reason the Swiss law requires that the prospectus contain a statement concerning the economic history of the corporation; and the French Law requires that the prescribed "notice" contain the balance sheet for the last fiscal year.11 Those statutes, which, like the German law, require that the subscriber to the shares of the original capital stock must sign for the subscription on a subscription slip containing the articles of association and the contract of subscription, extend this requirement to the case where the subscription is for shares issued as part of an increase of capital stock,

107. Id. § 261e.

108. They cannot be forced to elect accountants.

109. Nussbaum, Garantien aktienrecitlicher Publizitaet (1932) 61 Jurustiscine WocuENSCERIFT 2583; Lansburgh in (1932) BANK 965.

110. Germany: HandelscesetzBucH (1897, 1931) §§ 279, 281.

111. Switzerland: Law of July 8, 1919, art. VIII.

112. France: 2 PIC, op. cit. stlpra note 25, n. 1080; Switzerland: Halistern, op. cit. supra note 77 , at 186 ; as to the required notice see supra note 43 . 
and add to it by requiring that the subscription slip in the latter situation contain also the date of the resolution of the shareholders for the increase of stock. ${ }^{113}$

Concerning the general attitude towards the disclosure requirements in the various Continental countries, there would appear to be a growing tendency to enlarge the field of publicity. This is well illustrated by the fact that all amendments of older statutes enlarge the list of facts which are to be disclosed, as is clearly shown, for example, by the recent development of the German law..$^{114}$ For this reason the French law, which has insufficient disclosure requirements, has been for many years the subject of severe attacks. Numerous drafts have been proposed to enlarge the disclosure requirements, but until now without any success. ${ }^{115}$

\section{III}

There remain for consideration ${ }^{110}$ the remedies available to a defrauded investor. Under American law, these are contained mainly in sections 11 and $12^{117}$ of the Securities Act: section 11 concerning untrue registration statements, and section 12 dealing with failure to file a registration statement and with untruths in prospectuses or oral communications. These remedies being not all-inclusive, are supplemented by all other rights of action that may exist at law or in equity. ${ }^{118}$ We have to distinguish two remedies, rescission and the action for damages.

\section{Rescission}

Section 11 of the Securities Act, as passed originally, altered the common law by giving the defrauded purchaser of a security the right to recover from all persons enumerated in section 11 the consideration paid upon the tender of such security. In the amended section 11, the action for rescission is withdrawn. Consequently the question whether that right of action is available to a purchaser against any other person than his immediate seller is to be decided by common law principles. Since the common law remedy of rescission can only be invoked by the buyer against his immediate seller, the buyer is vithout the remedy of rescission against the persons enumerated in section 11 . He cannot

113. Germany: HANDELSGESETZBUCH (1897, 1931) § 281.

114. Supra note 105 .

115. 2 Pic, op. cit. supra note 25, at n. 1081 et seq.

116. A description of the criminal provisions of the continental laws shall not be given because they are not particularly interesting.

117. § 17 of the Federal Securities Act "is concerned only with violations that give rise to injunctive actions by the Commission or to criminal proceedings when there is wilful avoidance of its specific terms." LASSER and Gersror, Fenerar SEccrimtrs Act Procedure (1934) 211.

118. $\S 16$ of the Federal Securities Act. 
rescind against them because there is no contractual relationship between him and these persons. ${ }^{119}$ This even defeats the possibility of rescission as against the issuer of the securities, since the latter usually does not sell the securities. immediately, but uses an intermediary for the distribution of the shares. ${ }^{120}$ Thus, under the Securities Act as it now stands, the action for rescission is governed by section 12, permitting the purchaser to rescind the purchase against his immediate seller if the security has been sold in violation of section 5 , which requires registration by the issuing corporation, or, if the buyer has been induced to enter into the bargain by untrue statements or omissions in a prospectus or oral communication, unless the seller can sustain the burden of proving that he was excusably ignorant of the untruth or omission.

While the continental legal systems reach results somewhat similar to those obtained under the Securities Act, the ways by which they reach these results are dissimilar. The continental legal rules cannot be easily described. The only safe statement that can be made is that the different legal systems try to limit the power of rescission in the interest of the creditors of the corporation. But the exact boundaries of this limitation are not always certain. This is especially true with respect to the German law.

According to the German system, followed in Austria and Switzerland, ${ }^{121}$ the subscriber of shares (as distinguished from a buyer) induced to subscribe by mistake, fraud or duress generally cannot invoke a rescission against the corporation, although this denial of a remedy departs from the principles governing ordinary contracts. ${ }^{122}$ But how far this rule reaches is a subject of much controversy. While the German Supreme Court has conclusively laid down this rule only where the attempt was to rescind the subscription contract after the corporation had been registered, ${ }^{123}$ and has stated in an obiter dictum that an in. vestor can rescind his subscription for mistake, fraud, or duress as long as a company is not registered, ${ }^{124}$ nevertheless, it is doubtful whether the subscriber has a power to rescind, even up to this moment. Assuming, however, that the subscriber has this power, he can, if he is an incorporator, prevent the registration of the corporation by withdrawing his

119. Shulman, Civil Liability and the Securilies Act (1933) 43 Yate L. J. 227, 231.

120. Barnett, supra note 1 , at 13.

121. Stlbernaget, Die Gruendung der Aktiengeseluschaft (1907) 147; Hatistein, op. cit. supra note 11, at 136.

122. Germany: BUERGerLiches Gesetzbuch (1896) $\S \S 119,123 ; 2$ K. Wietand, op. cit. supra note 9 , at 26 .

123. German Supreme Court, May 8, 1908, 68 Entscheidungen des Reichsgerichts in Zivilsachen 344; German Supreme Court, April 4, 1916, 88 Entscheidungen des Reichsgerichts in Zivilsachen 187. StaUB-PINNER, op. cit. supra note 100, at $\S 189$, Anmerkung 25.

124. German Supreme Court, June 10, 1913, 82 Entscheidungen des Reichsgerichts. In Zivilsachen 375. StaUb-PINNER, op. cit supra note 100, at $\S 189$, Anmerkung 26a. 
application for registration, or, if he is merely a subscriber, by obtaining an injunction forbidding the incorporators to apply for registration; and may thus accomplish a rescission before the corporation can register and thereby defeat his right of action. ${ }^{125}$

Most of the arguments of a purely dialectical character which have been advanced to sustain the rule against rescission, are not worth mentioning. There are only two arguments which are worth mentioning: the advocates of the rule lay stress on the theory that the subscription of stock is not only a contract between the corporation and the subscriber to take part in the capitalization of the corporation, but is also a public declaration of intention to be unconditionally liable up to the amount subscribed, a declaration upon which the public can rely. ${ }^{123}$ In the last analysis this argument rests upon the theory that the capital stock of a corporation is a trust fund for the benefit of the creditors of the corporation, from which it follows that the capital stock can not be diminished by allowing rescission of the subscription. The other argument advanced is a practical one: It has been pointed out that the temptation to rescind is very great only when the financial situation of the corporation is embarrassed and it is to be reorganized. And in this situation, to allow descission would add to the difficulties of reorganization of such embarrassed corporations. ${ }^{127}$

The situation of a busyer of stock, defrauded by his purchaser, is materially different from that of a subscriber to stock. ${ }^{128}$ A defrauded buyer, that is, a buyer induced to buy stock by the misstatement of a material fact, wilfully made, concerning the security, has undoubtedly a right to rescind as against his purchaser. In this case the arguments against rescission cannot be advanced, because the buyer's rescission does not diminish the capital stock. Though there are very few decisions covering this field, it seems to be settled that the buyer of stock has a right to rescind even against the corporation, if the corporation has sold its own repurchased stock and has defrauded the buyer during the bargain. ${ }^{129}$ From the general principle of the German civil law concerning rescission for fraud, however, it may be deduced that, unless the seller was aware of the fraud, the buyer has no right to rescind against his seller where the fraud was committed not by the seller himself, but rather, by the issuer (or his agents).$^{100}$ Further, the buyer

125. Goldschntr, Die Axtiengesecischaft (1927) § 189, Anmerling 26.

126. Goldscrarm, op. cit. supra note 125 , at $\S 189$, Anmerkung $25 ; \mathrm{K}$. WIIILid, op. cit. supra note 9 , at 24 , note 26 .

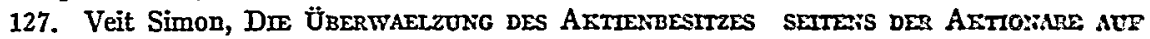
die AzIIENGESeLLSCHAFTs (1913), 7 Leipziger Zeitschrift 11.

128. German Supreme Court, June 2, 1916, 88 Entscheidungen des Reichsgerichts in Zivilsachen 271; Goldschmit, op. cit. supra note 125, § 189, Anmerkung 30.

129. See the citations in the preceding note.

130. Germany: BunRGerutches Gesetzbuci (1896) § 123. 
has no right of action for breach of warranty of quality against his seller if the value of the shares does not come up to the purchase price. ${ }^{131}$

Only a few legal writers disagree with the principles developed by the German Supreme Court. They try to limit the fundamental rule by pointing out that the reasons advanced by the advocates of the rule against rescission hold good only in cases in which the capital stock of the corporation is diminished by allowing a rescission, as partly shown by the fact that nearly all decisions of the German Supreme Court laying down the rule dealt with bankrupt corporations. These dissenting writers propose therefore to amend the rule by allowing rescission wherever the refunding can take place out of an earned surplus. ${ }^{132}$ The German Supreme Court, however, has declined to follow these suggestions because their application would be too difficult. ${ }^{133}$

The opinion advanced by the dissenting German textwriters which resembles the principle laid down by the English courts and those of Massachusetts, denying rescission after insolvency of the corporation, ${ }^{134}$ bridges the gulf between the German and the French point of view. While the French law permits on principle the rescission of a subscription induced by fraud or mistake, it is unanimously held by the French courts that the power to rescind cannot be invoked to the detriment of creditors of the corporation. ${ }^{135}$ If, for example, the creditors of a cor-

131. German Supreme Court, January 26, 1915, 86 Entscheidungen des Reichsgerichts in Zivilsachen 146; GoLDSCHMIr, op. cit. supra note 125, § 189, Anmerkung 33.

The German law concerning warranty of quality is similar to the American law under the Uniform Sales Act. Kessler, Kanfertrag, Sachmängel, in 4 Recursvercuercursdis HANDWÖRTERBUCH (1932) 727, 754.

132. $2 \mathrm{~K}$. WIELAND, op. cit. supra note 9, at page 26; Breit, Ansprueche der Aktiontaero gegen die Aktiengesellschaft aus dem Erwerb der Aktien (1915) 76 Zeitschrift fuer Handds* recht 415 .

133. German Supreme Court, April 4, 1916, 88 Entscheidungen des Reichsgerichts in Zivilsachen $189 ; 2 \mathrm{~K}$. WIEtand, op. cit. supra note 9, at 26, n. 32.

134. Henderson v. Royal British Bank, 7 E. \& B. 356 (Q. B. 1857); Dalles v. Turquand, L. R. 2 H. L. 325, 344 (1867); Commissioner of Banks v. Cosmopolitan Trust Co., 253 Mass. 205, 148 N. E. 609 (1925). Concerning the majority rule, see Barlantine, CoRPORATIONS (1927) 149 et seq.

135. Many questions concerning rescission are left in doubt by the decisions of tho French courts. It is not settled whether, or to what extent the rescission of a subscription for fraud makes the corporation void from the beginning. See HEMsard, Tureoks ET Pratique des Nuluttés des Societés ex des Sociétés de Fat (1926) 112 et seq.

It is one of the main defects of the French corporation law that nearly every violation of the rules concerning the founding of the corporation makes the corporation void from the beginning. Law of July 24, 1867, 234 BuxLerrN Des Lors 94, art. 22, 23, 24, 25, 41, 42-56. The French courts have only inadequately tried to improve this situation by treating such corporations as having a sort of de facto existence. In contrast to the American law, which requires a quo warranto proceeding to liquidate the de facto corporation, every shareholder, shareholder's personal creditor and creditor of the corporation has a right of action to declare the corporation void. As soon as the corporation has been declared void by a decree of the court, it is liquidated. For a comparison of the 
poration who have not received full satisfaction of their claim sue the shareholder directly, as they may under French law, the defrauded shareholder is not allowed to rescind by way of defense. The same principle governs if the liquidator sues for the payment of the subscription price. ${ }^{136}$

\section{Action for damages}

There are some striking discrepancies between the American and the continental laws relating to the investor's action for damages. Under the provisions of section 11 of the Securities Act, any person acquiring a security may invoke an action for damages upon showing proof that on the date the registration statement became effective it contained (1) either an untrue statement of a material fact or (2) omitted to state a material fact required to be stated therein, or necessary to malee the other statements not misleading. Departing from common law principles governing actions for misrepresentation and fraud, section 11 does not require that the complaining purchaser be actually misled by the registration statement; for the statute creates an absolute presumption that the purchase is made on the strength of the facts set out in the registration statement. Since the amendment of the Act, this rule is, however, subject to one important exception to the effect that, if the purchaser has acquired the security after the issuer has published an earning statement covering a full year subsequent to the effective date of the registration statement, the purchaser must prove that he relied on the untruth or omission in the registration statement.

The liability under section 11 falls not only upon the immediate seller, but also upon a large group of persons, issuers, directors, and officers, experts and underwriters, who can be sued jointly and severally. While the liability of the issuer is an almost absolute one, ${ }^{137}$ all other persons made liable by section 11 may escape liability under the specific defenses enumerated in the Act. Thus, for example, these persons can defend an action for damages brought against them by proving that they had severed relationships with the issuer or attempted to do so

French and American systems, see Kessler, Die Jfangelliafte Aktiengesellscliaft des nordamerikanischen Rechts als de facto corporation, corporation by estoppal axd furtnerslits in Vergleich mit der societe de fait par actions des fransoesisclsen Rechts (1929) 3 Zetrschrift fUer aUSLaendiscaes UND internationales PrTutrochi 465 et seq. The Belgian and Italian law have diminished the number of the defects which malie the corporation void from the beginning. See $2 \mathrm{~K}$. WIIIANo, op. cit. supra note 9, st 83 .

136. 1 Copper Royer, Tratte des SOcteres Axomyars (3d ed. 1925) n. 50; 1 Hourri et Bosvreux, op. cit. sufra note 7, n. 646; Paris, Cour d'Appal, April 26, 1877; Dalloz Jurisprudence, 1879 II 81 . French Chambre des Requêtes, November 8, 1904, Gazette des Tribunaux, 1905 I 29; French Cour de Cassation, February 10, 1868, Dalloz Jurisprudenes, 1868 I 379.

137. Federal Securities Act \& 11 (b). 
before the registration statement became effective and, in addition, by further proving that they had notified the Securities Exchange Commission and the issuers at that time of the steps taken and that they would not be responsible for the registration statement. ${ }^{138}$ Furthermore, they can escape liability by proving that the registration statement became effective without their knowledge, ${ }^{130}$ or, finally, by proving a reasonably grounded belief in the accuracy and completeness of the registration statement, arrived at after reasonable investigation. ${ }^{\mathbf{1 1 0}}$ Finally, the defendant may minimize the damages insofar as he can prove that they were not a consequence of the untruth in the registration statement. ${ }^{141}$ The measure of damages recoverable under Section 11 varies according to whether the purchaser has sold or retained tho securities and if he has sold them, whether sale was made before or after the suit was begun. ${ }^{142}$ In no case can the purchaser recover more than the price at which the securities were offered to the public. ${ }^{143}$

The liability of the seller for damages under section 12 of the Securities Act is governed by the same principles as the liability to refund the purchase price under the same section.

The various continental laws differ widely with respect to the main ideas as well as to the details of regulation. The difficulty in giving an adequate picture of the provisions of the continental laws with respect to the investor's right of action for damages is increased by the fact that many of the provisions are not at all clear. This lack of lucidity which characterizes especially the German and the Swiss provisions is explained by the fact that the fundamental liability provisions are only indirectly connected with the issuance of shares and are mainly to be found, for example, among the general provisions concerning irregularities during the founding of the corporation. It is rather doubtful to what extent the remaining gaps can be filled out by the general principles of delictual liability.

The rules of the French law are much less complicated. They are characterized by two main peculiarities: first, the most important provisions imposing liability on the guilty persons in the interest of a defrauded investor cannot be found in the corporation act. For, while the French corporation Act ${ }^{144}$ contains a very broad provision imposing on incorporators and administrators a liability for damages, if the corporation has been declared void for non-compliance with the statutory requirements, nevertheless, this important paragraph covers only a very small sector of the field we are now interested in. The section is of importance, for example, in cases of fictitious subscriptions, ${ }^{145}$ or if the

138. Id. $\S 11$ (b) (1).

140. Id. $\$ 11$ (b) (3).

142. Id. \& 11 (e).

144. Law of July 24, 1867, 234 BuLLetion DES LoIs 94, art. 42.

145. French Cour de Cassation, August 6, 1862, Dalloz Jurisprudence 1862 I 428.
139. Id. \& 11 (b) (2).

141. Id. $\S 11$ (e).

143. Id. \& $11(\mathrm{~g})$. 
prescribed twenty-five percent on each share has not been paid in.1*0 or if the publicity requirements of the act have not been complied with. ${ }^{147}$ But, since it stipulates as a condition precedent to any liability that the corporation must have been declared void, it does not cover, for example, the cases of a fraudulent over-valuation of assets, ${ }^{149}$ of untrue statements or omissions in the prescribed "notice," in the journal officiel or in the balance sheets and profit and loss statements of prospectuses. ${ }^{149}$ These very important situations, however, are covered by the general and broad principles of the law of torts. The fact that the famous article 1382 of the Civil Code, invoked by the courts to cover this situation, gives everybody who has suffered damages a right of action against the guilty wrongdoer, ${ }^{150}$ has enabled the French courts, especially in the famous Credit Mobilier Cases, to draw the border of civil liability as wide as necessary. ${ }^{151}$

The question arises at this point as to who may be made liable for damages under the continental laws, and to whom, and under what conditions they might be liable.

The issuing corporation under continental law is never liable to a subscriber for damages for untrue statements. Those legal systems which do not allow a rescission of a subscription for mistake, fraud or duress cannot allow an action for damages to a defrauded subscriber against the corporation, or else the restrictions concerning rescission could easily be evaded. This principle is clearly stated by the German courts and by the German and Swiss writers. ${ }^{152}$ Since it could not be ascertained whether the problem has been the subject of decisions of French courts, the only safe statement that can be made with respect to the French law is that the French writers do not mention any liability

146. French: Cour de Cassation, January 27, 1873, Dalloz Jurisprudence, 1873 I 331.

147. France: Law of July 24, 1867, 234 BuLLETn Des Lors 94, art. 56.

148. HéMaARd, op. cit. supra note 135 , at $n$. 257 et seq.

149. 2 PIC, op. cit. supra note 25 , at n. 1028.

150. In this respect the French law differs widely from the German and the common Iaw, both of which have no such broad principle of delictual liability, but, rather, only a

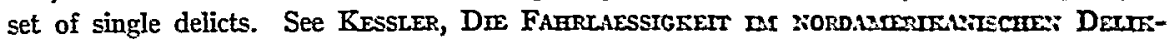
TERECET (1932) 61. Concerning wilful harms see, however, the statement of Lord Bowen in Skinner \& Co. v. Shev \& Co. [1893] 1 Ch. 413, 422.

151. Cour de Paris, August 1, 1868, Dalloz Jurisprudence, 1869 II 65; French Cour de Cassation, May 7, 1872, Dalloz Jurisprudence, 1872 I 233; Cour de Cassation, Novemtar 11, 1873, Recueil Sirey, 1874, I 97 annotated by Labbé; see further 2 Vavacseur, Traité des Sociétés civiles et commerciales (5th ed. 1897-1904) n. 91-133 and Wiener, Die Errichtung den Aktiengesellschaft und die Grunderverantwortlichkeit (1579) 24 Zeitschrift fur Handelrecht 1 ; (1880) 25 id. at 8 , n. 18.

152. German Supreme Court, March 14, 1903, 54 Entscheidungen des Reichsgerichts in Zivilsachen 128; German Supreme Court, April 4, 1916, 88 Entscheidungen des Reich:gerichts in Zivilsachen 187; Silbernagel, op. cit. supra note 121, at 147. 
of the corporation for damages based on the ground that the corporation through its agents has committed a wrong on the defrauded subscriber.

According to the decisions of the German Supreme Court, the situation of a buyer of stock is quite different, due to the same practical considerations already discussed in connection with rescission. He is granted an action for damages against the corporation if he has, for example, purchased treasury shares from it, in reliance on untrue statements made by its principal officers. ${ }^{163}$

The problem arises next, as to what persons other than the corporation might be liable for damages. The great difficulties we shall meet here do not concern so much the problem as to what persons are liable, as the problem to whom these persons are liable, and under what conditions.

In order to determine who else might be liable, it is first necessary to consult the provisions providing for liabilities for non-conforming with the rules regulating the formation of the corporation. In some countries we can find broad rules which impose civil liability on those persons to whom irregularities in the organization process may be attributable. According to the German law, the incorporators and the members of the boards of directors and of supervisors are liable for untrue statements made in the documents which have to be filed for purposes of registration with the judge in charge of the commercial register. ${ }^{154}$ The same liability is extended to all persons who participate in any irregularities which may occur during the organization process. ${ }^{150}$ From this point of view those persons, for example, who have transferred overvalued assets to the corporation in exchange for shares are liable.100 Similar provisions exist under the Swiss law. ${ }^{167}$ In the case of the French law, these persons are liable under the provisions of the corporation statute or the general principles of delictual liability. ${ }^{168}$

So much for the persons who might be liable for irregularities in the founding of a corporation. Coming now to the question, to whom these persons might be liable, we must distinguish an older type of legislation, represented by the French law, a more modern type, represented by the German law, and finally a type combining these two, represented by the Swiss law.

According to the French law, incorporators or directors who are guilty of irregularities which have made the corporation void from the begin-

153. GordscHMIT, op. cit. supra note $125, \S 189$, Anmerkung 30 ; see further the citations in the preceding note.

154. Germany: HandetscesetzBuCH $(1897,1931) \S \S 202$ (1) (2) 204. The members of the board of directors and of the board of supervisors are only secondarily liable.

155. Id. \& 202 (5).

156. Id. § 202 .

157. Switzerland: ObLigationeanrecent (1911) art. 671.

158. Supra note 1160 et seq. 
ning are liable only to the shareholders, and not to the corporation; but where they may be guilty of fraudulent devices other than such as void the corporation, they are liable in damages to both parties. ${ }^{15 s}$ To the group of shareholders who can sue for damages belong not only the original subscribers, but also all buyers of stock who have acquired stock either in reliance on the regularity of the founding or on the untrue statements. ${ }^{159}$ If the corporation has been declared void, the shareholders can claim the damage they have suffered by the premature liquidation of the corporation. ${ }^{160}$ In other cases the damages are measured either by the difference between the subscription price and the market value of the shares, or by the amount of the whole consideration paid for the subscription. ${ }^{101}$ If they have sold their shares, they may get the difference between the purchase price and the selling price. In all cases, however, the courts have a very wide discretion in measuring the damages. ${ }^{i 63}$

The German law has reached an opposite solution. According to the special provisions of the German Commercial Code, the guilty incorporators and their associates are not liable to the individual shareholder, but only to the corporation, itself. ${ }^{104}$ If, for example, they have made untrue statements as to the total subscription of the capital stock, they have to subscribe the missing balance. If the shares are not paid up to at least one quarter of their nominal value, they have to pay the unpaid instalments. If property transferred in exchange for shares has been overvalued, they have to pay the difference between the real and the estimated value of the property. ${ }^{105}$ The power to decide whether the guilty persons may be sued is within the discretion of the board of directors, or, if the latter are to be sued, the board of supervisors. A suit must be brought, if it is desired, by either a majority in voting power of the shareholders or by a minority of one tenth in amount of the capital stock. ${ }^{160}$

According to the Swiss law, every person who has taken part wilfully

158a. Concerning the corporation's right of action and the right of the shareholder to sue in the name of the corporation, see the annotation of Labbs in Recueil Sirey 1835 I 97.

159. French Cour de Cassation, December 30, 1872, Dalloz Jurieprudence, 1873 I 333 ;

French Cour de Cassation, July 2, 1873, Dalloz Jurisprudence, 1874 I 49.

160. Wiener, supra note 151 , at $6, \mathrm{n} .13$.

161. Wiener, supra note 151 , at 7 .

162. SIIBERNAGEI, op. cit. stpra note 121, at 426 .

163. Ibid.

164. Germany: HANDELSGESETzBDCE $(1879,1931) \S 202$. It is rather doubtiul whether, in addition to this liability to the corporation, the persons enumernted in $\$ 202$ are liable to shareholders in case of intentional harm. See Gordscromr, op. cit. sufro note 125, \$ 202, anmerkung 12 .

165. Goldscenmi, op. cit. supra note $125, \S 202$, anmerkung 5 .

166. Germany: HandexsgesetzBdCh $(1879,1931)$ \& 268. 
in irregularities during the formation process is liable for damages to the corporation as well as to the individual shareholder. ${ }^{107}$ But the corporation has a prior right insofar as a vote in a shareholders' meeting discharging the persons liable precludes the individual shareholder who has either assented, or who does not start a suit within six months after the vote, from bringing suit against the persons thus discharged. ${ }^{108}$

So much for the persons liable for irregularities in the founding of the corporation, and the parties to whom they may be made liable. The various laws have similar provisions against fraudulent transactions in connection with the increase of the capital stock. ${ }^{160}$

To the group of persons who might be liable, either before or after the founding, belongs finally the bank which has made untrue statements in prospectuses or the like, unless it can sustain the burden of proving excusable ignorance of the untruths. ${ }^{170}$ According to the German law the bank is liable only to the corporation itself. ${ }^{171}$

\section{IV}

In summing up, if we compare the continental security legislation with the Securities Act, we must reach the conclusion that the investor is a good deal better protected under the Securities Act than under the various continental laws. The writer has no doubt that the superiority of the Securities Act over all continental laws will strengthen the position of the proponents of reform of the continental systems; and that the Securities Act will serve as a model for future continental legislation.

The superiority of the Securities Act is especially evident in two respects: first, in the respect that the Act creates a permanent supervisory body with broad powers to administer its provisions, ${ }^{172}$ a feature which none of the continental legal systems possess; ${ }^{173}$ second, in the respect that the disclosure requirements under the Securities Act go a good deal further than those under the various continental systems. Compared with the disclosure requirements under the Securities Act, those under many continental legal systems, especially the French law, are trivial. We cannot find any counterparts in the continental statutes to many of the provisions contained in the 34 sections of Schedule A of the Securities Act. For example, the continental statutes do not contain requirements concerning disclosure of security ownerships, as

167. Switzerland: Obligationenrecht (1911) art. 671.

168. Id. art. 675 .

169. HaLISTEN, op. cit. supra note 11 , at 185 et seq.

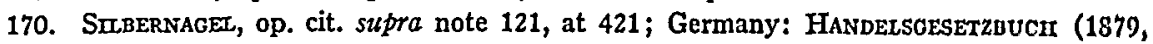
1931) $\S 203$.

171. Germany: Handelsgesetzbuch $(1879,1931)$ \& 203.

172. Supra page 1142 .

173. Supra page 1142. 
do sections 6,7 , and 10 of Schedule A; nor are there provisions prescribing disclosures of the salaries of directors and other officers in most of the continental statutes. Only the German law approaches section 14 of Schedule A, dealing with disclosure of such salaries. None of the continental statutes require disclosure of every "material contract" such as is required by the Securities Act; nor is there a requirement of specific information concerning the purposes of issues to be sold, such as is required by section 13 of Schedule A of the Securities Act. The reason that sections 15, 17, and 18 of Schedule A of the Securities Act, requiring disclosure of commissions paid to underwriters, have no real counterparts in the continental laws is that the continental legislators have been of the opinion that the investor is sufficiently protected by the prohibition of the issuance of shares below par and by the requirements that any special advantages given by the corporation to its incorporators, and any expenses of incorporation which have to be borne by the corporation, have to be disclosed. That the continental legal systems have left a gap open in this respect is proved by the fact that the commissions which are to be paid to the banks for the distribution of shares, even if these commissions mean that in effect the shares are being issued below par, ${ }^{174}$ are not required to be disclosed and such disclosure is in most countries omitted in actual corporate practice. ${ }^{105}$

The lack in the continental laws of requirements parallel to those of the Securities Act is due in the case of some of the requirements, however, to the less complicated financial structure of the continental corporations. This is the reason for the lack of disclosure requirement relating to shares without par value; for the continental laws, with the exception of Belgium, ${ }^{176}$ do not recognize this class of shares. The same is true for the lack of disclosure requirements concerning certificates of deposit and voting trusts, both being either unknown or of no importance in most continental countries. ${ }^{177}$

174. The legal validity of such "evasions" of the prohibition to issue shares below par under the German law seems to be unanimously admitted. See Ruth, Eigne Altien und Verwaltungsaktien (1928) 44 (Gesellschaftsrechtliche Abhandlungen, herausgegeben von Nussbaum); Staud-PnnNER, op. cit. supra note 100, \& 184, Anmerkung 1. Under the French law, however, the validity of such transactions seems to be rather doubtiul. Sae 2 Lyon-Caen et Renault, op. cit. supra note 17, n. 725 et seq. In many cases the commissions paid to the investment bankers consist in the difference between the subscription price they have to pay and the redistribution price. RUII, at 44.

175. 2 FredericQ, DroIt CONIJIERCIAL belCe (1930) n. 851.

176. See PAssow, op. cit. supra note 22, at 160 et seq.; Flechtheim, Vom Aliticraresern

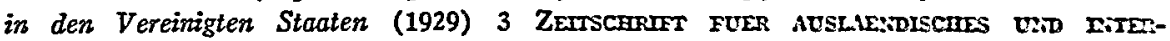
mattonales Privatrecert 117 et seq.; Halistem, op. cit. supre note 11, at 100; 1 Eisfeld, DAS NIEDERIAENDISCHE BANKWESEN (1916) 106 et seq. 